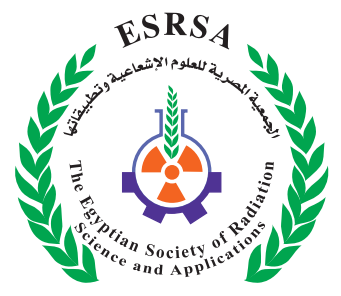

J. Nucl. Tech. Appl. Sci., Vol. 9, PP. 19 : 31 (2021)

\title{
Biosynthesis of Lovastatin by Gamma Irradiated Aspergillus Terreus
}

Saadia, M. Easa ${ }^{1}$, Mattar, Z.A. ${ }^{2}$, Khalaf, M.A. ${ }^{2}$ and Khalil, M. F.A. ${ }^{2}$

Received: 20/12/2020

Accepted: 10/04/2021

DOI: $10.21608 /$ jntas.2021.54136.1031

E.mail:dr01khalaf@hotmail.com

\section{KEYWORDS}

Aspergillus

terreus., Lovastatin,

Biosynthesis, Gamma

radiation.

\section{ABSTRACT}

Lovastatin $\left(\mathrm{C}_{24} \mathrm{H}_{36} \mathrm{O}_{5}\right.$, Mevinolin, Monacolin $\mathrm{K}$ and Mevacor $\left.{ }^{\circledR}\right)$ is the first compound of its kind to become available for treatment of hypercholesterolemia. This fungal secondary metabolite is produced by Aspergillus, Monascus and Penicillium species, via the polyketide synthase (PKSs). The role of hypercholesterolemia as a risk factor for atherosclerosis, and ischemic heart disease was indicated by the clinical, epidemiologic and pathologic studies.

In the present study, gamma irradiated of selected highly lovastatin producer Aspergillus terreus isolate (A. terreus S3 $\gamma 8$ ) was employed for lovastatin production in submerged fermentation $(\mathrm{SmF})$ conditions. Different fermentation parameters including: incubation period, initial $\mathrm{pH}$ of the medium, temperature, different carbon and nitrogen sources, type of inoculum and agitation; were carried out under $\mathrm{SmF}$ conditions to enhance the lovastatin production. The maximum lovastatin production $(547.33 \mathrm{mg} / \mathrm{l})$ was achieved at initial $\mathrm{pH} 6$, incubation temperature $30^{\circ} \mathrm{C}$, agitation rate $150 \mathrm{rpm}, 4 \%$ soluble starch and $0.3 \%$ yeast extract as carbon and nitrogen sources, respectively, after 8 days when the production medium (which containing bio-elements: $\mathrm{KH}_{2} \mathrm{PO}_{4}, \mathrm{MgSO}_{4}$ and $\mathrm{MnSO}_{4}$ ) was inoculated with $48 \mathrm{~h}$ age from seed culture inoculum.

1. Microbiology Dept., Faculty of Science, Ain Shams University, Egypt.

2. Radiation Microbiology Dept., National Centre for Radiation Research and Technology (NCRRT), Egyptian Atomic Energy Authority (EAEA). P. O. Box: 29 Nasr City, Egypt. 


\section{.INTRODUCTION}

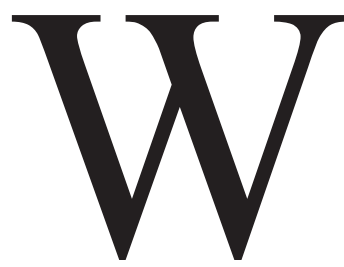

orld Health organization (WHO) estimated till 2015, Non communicable diseases (NCDs) have been caused about 40 million deaths. It

was reported that globally cardiovascular diseases (CVDs) are the major cause of these deaths than any other cause due to NCDs deaths. Among four major death causes of NCDs, CVDs accounts 45\% (about 17.7 million deaths. Further, it was reported that low and middle income countries are affected more than $3 / 4$ of CVD deaths than others (WHO, 2017). This is related to high levels of cholesterol in plasma, since hypercholesterolemia is primary risk factor of atherosclerosis and coronary artery disease (BarriosGonzalez and Miranda, 2010). It has also been reported that high cholesterol level increases the risk of several nervous system diseases like dementia/Alzheimer's disease Ischemic heart stroke (IHS). Further, hypercholesterolemia stimulates the chances of diabetes development, obesity and certain types of cancers (Munir et al., 2018).

Generally, only one-third of the total body cholesterol is diet-derived; while two-thirds are synthesized by the liver and, to a lesser extent by other organs (Furberg, 1999). For this reason, control of cholesterol by inhibiting its biosynthesis is an important strategy to lower cholesterol levels in blood.

Statins are a group of drugs that selectively inhibit the enzyme 3-hydroxy-3- methylglutarylcoenzyme A (HMG-CoA) reductase, the regulatory and rate-limiting enzyme in cholesterol biosynthesis (Bizukojc and Ledakowicz, 2015). In this way, these compounds lower cholesterol; particularly low density lipoprotein (LDL) or low den sity cholesterol ("bad cholesterol"); while slightly increasing highdensity lipoprotein cholesterol ("good cholesterol"), thus, preventing plaque buildup inside the arteries.
Moreover, statins have emerged at the forefront of preventive drugs for cardiovascular disease because of a substantial clinical trial database demonstrating that statins reduce the risk for coronary artery disease morbidity and death across a broad range of at-risk patient cohorts. A different group of studies have shown that statin therapy has biological effects beyond the level of LDL cholesterol. These new studies have discovered numerous new biological (pharmacological) activities of statins; representing potential application in diseases like cancer, Alzheimer's dementia and age-related bone loss. Statins are lovastatin and compactin, while pravastatin is derived from the latter by biotransformation. Simvastatin, the second leading statin in the market, is a lovastatin semisynthetic derivative.

Lovastatin $\left(\mathrm{C}_{24} \mathrm{H}_{36} \mathrm{O}_{5}\right.$, also known as mevinolin, monacolin $\mathrm{K}$, Mevacor) is a potent competitive inhibitor of HMG-CoA reductase. It is active not only in vitro to inhibit cholesterol biosynthesis but also in vivo to lower plasma cholesterol level in humans and animals (Chang et al., 2002 and Bizukojc and Ledakowicz, 2015), and is thereby effective in the therapy of hypercholesterolemia. Lovastatin was the first hypocholesterolemic drug to be approved by the United States Food and Drug Administration (Manzoni and Rollini, 2002). It has also been indicated as potential therapeutic agent for the treatment of various types of tumors because of its capability to suppress tumor growth in vivo through inhibition the synthesis of nonsterol isoprenoid compounds (Chang et al., 2002).

Different types of filamentous fungi including Penicillium species Aspergillus species, and Monascus species have higher capability for lovastatin production through fermentation technique. It was also reported that species of Scopolariopsis, Paecilomyces, Doratomyces, Pleurotus,Trichoderma, Phythium, Phoma, Gymnoascus and Hypomyces have also potential to produce lovastatin during the 
course of fermentation ((Munir et al., 2018 and Iewkittayakorn et al., 2020).

The traditional fermentation process involving SSF is labour-intensive, time-consuming and requires large cultivation areas, therefore the utilization of $\mathrm{SmF}$ technique for the production of fungal secondary metabolites has been studied to overcome the problems of space, scale-up and process control of SSF (Lai et al., 2005). It is well known that the culture medium has a significant influence on the biosynthesis of lovastatin and its rate of production. Selection and composition optimization of an optimum medium is therefore important for establishing a process for producing lovastatin (Li et al., 2011; Suwannarat et al., 2019 and Subhan et al., 2020).

Although mutation breeding is an effective method of improving the production of lovastatin, and many mutagenic techniques have been used to improve the productivity of $A$. terreus, to our knowledge, there have been nil reports of using gamma irradiation to induce high-yield lovastatin mutants of A. terreus (Gu et al., 2008 and Li et al., 2011)

The objective of this study is to investigate lovastatin production by gamma irradiated Aspergillus terreus (local isolated strain) in submerged $(\mathrm{SmF})$ conditions.

\section{MATERIALS AND METHODS}

\section{Microorganisms and inoculum preparation:}

The Aspergillus terreus isolates used in this study were obtained from Industrial Microbiology Laboratory, National Center for Radiation Research and Technology (NCRRT), Nasr City, Cairo, Egypt. The isolates were cultured on Potato Dextrose Agar (PDA, Oxoid, 2006) slants at $25^{\circ} \mathrm{C}$ for 10 days, and then stored at $4^{\circ} \mathrm{C}$, and sub cultured every 3 months. A suspension of spores was prepared by washing PDA slants cultures with a sterile saline solution of $0.1 \%$ Tween- 80 . The spore concentration was deter- mined by direct plate counts of spores in suspension and adjusted to $10^{6}$ spores $/ \mathrm{ml}$ by diluting it suitably. A spore suspension of this concentration was used as inoculum.

\section{Screening of lovastatin producer isolates on broth medium:}

The screening for lovastatin production was carried out with nine isolates of $A$. terreus. The screening was carried out in Erlenmeyer flasks $(250 \mathrm{ml})$ each containing $50 \mathrm{ml}$ of different sterile production media (PMI, Manzoni et al., 1998; PMII, Su et al., 2003; PMIII, Chang et al., 2002; PMIV, Manzoni et al., 1998 and PMV, Sayyad et al. 2007). The flasks (initial $\mathrm{pH}$ 6) were inoculated with $1 \mathrm{ml}$ spore suspension $\left(10^{6} \mathrm{CFU} / \mathrm{ml}\right)$ from each tested isolate. The inoculated flasks were incubated at $30{ }^{\circ} \mathrm{C}$ at 6 and 12 days at $150 \mathrm{rpm}$. After incubation period, the fermented culture media were extracted by ethyl acetate and the organic phase was used to determine the lovastatin content. Also, microbial growth was determined by drying the biomass on filter paper for $24 \mathrm{~h}$ at $65^{\circ} \mathrm{C}$ to a constant weight. The highly producer lovastatin isolate was selected and used for further investigation in this study.

\section{Induction of active isolates:}

Three milliter of highly producer lovastatin $A$. terreus spores $\left(10^{6}\right.$ spores $\left./ \mathrm{ml}\right)$ were exposed to gamma radiation at dose $4 \mathrm{kGy}$ (sub lethal dose) which kill about $99.99 \%$ of survival spores. Irradiation was carried out at the National Center for Radiation Research and Technology (NCRRT), using ${ }^{60} \mathrm{Co}$ gamma irradiation source of gamma chamber (4000A) with a dose rate $1 \mathrm{kGy} / 52 \mathrm{~min}$ at the time of the experiment.

The irradiated spores were grown for 4 days on PDA plates and the purified survival irradiated colonies (26 colonies) were picked up and grown on lactose-yeast extract agar medium for 7 days at 
$28^{\circ} \mathrm{C}$. After incubation the rapid screening method (Vilches Ferron et al., 2005) was used for isolating lovastatin overproducing irradiated isolate of $A$. terreus. Also, the higher lovastatin producer irradiated isolates were screened for lovastatin production in broth suitable PM.

\section{Lovastatin production parameters}

The highly irradiated lovastatin producer $A$. terreus isolate was selected for the investigation of some conditions affecting lovastatin production from the best selected production medium in flask batch cultures. Batch fermentations were carried out in 250 $\mathrm{ml}$ Erlenmeyer flasks containing $50 \mathrm{ml}$ of PM. A set of experiments was performed at different period (212 days), $\mathrm{pH}$ (4-8) temperature $\left(20-35^{\circ} \mathrm{C}\right)$, eight carbon sources $(30 \mathrm{~g} / \mathrm{l})$, eight nitrogen sources $(3.86 \mathrm{~g} / \mathrm{l})$, type of inoculum (spore suspension, seed culture and mycelium disc) and aeration to investigate the effect of these parameters on the lovastatin production. For preparation of seed culture $1.0 \mathrm{ml}$ of fungal spore suspension $\left(2 \times 10^{7} \mathrm{CFU} / \mathrm{ml}\right)$ was inoculated in seed culture medium (Yeast Malt Extract, Oxoid, 2006) and incubated under shaking $(150 \mathrm{rpm})$ at $30{ }^{\circ} \mathrm{C}$ for 2 days. After 2 days, $5 \mathrm{ml}$ of the fungal growth was used as inoculums $(10 \mathrm{v} / \mathrm{v})$. For preparation of mycelium fungal growth, the fungus was inoculated on PDA plates at $28^{\circ} \mathrm{C}$ for 7 days. After that the fungal growth was cut into $1 \mathrm{~cm}$ discs by sterile cork porer, and one disc was used as inoculum.

\section{Analytical Methods:}

The lovastatin in the fermented culture was determined according to methods described by Hajko et al. (1998); Kumar et al. (2000) and Li et al. (2011) with some modifications. The fermentation broth was adjusted to $\mathrm{pH} 3.0$ using $\mathrm{HCl}$ (36\%), after which an equal volume of ethyl acetate was then added. After shaking at $180 \mathrm{rpm}$ for $12 \mathrm{~h}$ at ambient temperature, the fermentation broth and the mycelium pellets were filtrated through preweighed mem- brane filters and the residual biomass was washed three times with distilled water. The biomass was determined by gravimetric analysis after the mycelium pellets were dried at $65^{\circ} \mathrm{C}$ to a constant weight. The organic and aqueous phases from the filtrate were separated in a separating funnel. The organic phase was dried under vacuum at $45^{\circ} \mathrm{C}$. The dried residue was dissolved in $5 \mathrm{ml}$ of $75 \%$ ethanol and used to determine the lovastatin content against known concentration of pure lovastatin. Lovastatin contents were determined by the dual-wavelength UV spectrophotometry method. To verify the efficiency of this method, extraction of blank (fermented culture without inoculation) and known concentration (20 mg) of pure lovastatin (as internal standard) in fermented culture was carried out at the same conditions. Verification of lovastatin contents were detere mined by through scanning between 190-1100 nm by using UV/Visible Spectrophotometer (type Helios Gamma) to determine the maximum absorbance $\left(\lambda_{\max }\right)$ wavelength of the produced lovastatin and the standard concentration $(20 \mathrm{mg}$ ) of pure lovasatatin. The $\lambda_{\max }$ showed maximum reading was fixed and used for determining of extracted produced lovastatin in this study.

Residual sugar was measured by the phenol sulphuric acid method (Southgate, 1976) using glucose as standard

\section{RESULT AND DISCUSSION}

\section{Screening of some isolates for lovastatin produc- tion}

Nine A. terreus isolates were screened in specific lovastatin production broth media (table 1). It was found that 7 isolates of $A$. terreus have the ability to produce lovastatin. The highest lovastatin concentration $(64 \mathrm{mg} / \mathrm{l})$ was recorded by $A$. terreus isolate number 3 (A. terreus $\mathrm{S} 3$ ) after 12 days from PMII medium. Manzoni, et al. (1999) found that of 
all Monascus and Aspergillus strains investigated for statins production, M. paxii AM12M, an isolated spontaneous mutant, yielded $127 \mathrm{mg}$ lovastatin/l.

Culture media for microbial lovastatin production are very diverse, ranging from defined compositions to natural ones. The results of lovastatin produced by $A$. terreus in this study indicated that the PMII medium was the best medium for lovastatin production. The production medium PMII consists of (g/l): Dextrose, 30; $\mathrm{NH}_{4} \mathrm{Cl}, 3.86 ; \mathrm{KH}_{2} \mathrm{PO}_{4}$; $\mathrm{MgSO}_{4} \cdot 7 \mathrm{H}_{2} \mathrm{O}, 0.86 ; \mathrm{MnSO}_{4} \cdot 4 \mathrm{H}_{2} \mathrm{O}, 0.19$ (Su et al., 2003). The main carbon and nitrogen sources in this medium were dextrose $(30 \mathrm{~g} / \mathrm{l})$ and $\mathrm{NH}_{4} \mathrm{Cl}(3.86 \mathrm{~g} / \mathrm{l})$, respectively, thus confirming the importance of this medium for high lovastatin yields by $M$. purpureus MTTCC 369 (Sayyad et al., 2007). On other hand Chang, et al. (2002); Sayyad, et al. (2007) and Li, et al. (2011) observed that the components of the complex culture media used for Monascus and Aspergillus lovastatin production include several sugars (most commonly glucose, lactose and glycerol) organic nitrogen sources (peptones and yeast extract) or inorganic nitrogen (ammonium and nitrates).

Table (1) : Fermentation yields ( $\mathrm{mg} / \mathrm{ll}$ ) of lovastatin by different A. terreus isolates from different media after 6 and 12 days. (growth conditions: $\mathrm{pH}$,6; temp. $30^{\circ} \mathrm{C}$; agitation rate, $150 \mathrm{rpm}$ ).

\begin{tabular}{|c|c|c|c|c|c|c|c|c|c|c|}
\hline Different culture & \multicolumn{2}{|c|}{ PMI } & \multicolumn{2}{|c|}{ PMII } & \multicolumn{2}{|c|}{ PMIII } & \multicolumn{2}{|c|}{ PMIV } & \multicolumn{2}{|c|}{ PMV } \\
\hline A. terreus isolates & 6 & 12 & 6 & 12 & 6 & 12 & 6 & 12 & 6 & 12 \\
\hline S1 & 14 & 38 & 11 & 35 & 20 & 48 & 16 & 37 & 12 & 26 \\
\hline $\mathbf{S 2}$ & 18 & 46 & 16 & 47 & 14 & 39 & 12 & 34 & 11 & 31 \\
\hline S3 & 22 & 56 & 28 & 64 & 20 & 58 & 18 & 43 & 17 & 52 \\
\hline S4 & ND & ND & ND & ND & ND & ND & ND & ND & ND & ND \\
\hline S5 & 15 & 47 & 20 & 53 & 19 & 46 & 14 & 39 & 14 & 35 \\
\hline S6 & 12 & 35 & 10 & 32 & 17 & 44 & 15 & 40 & 13 & 42 \\
\hline S7 & 13 & 30 & 15 & 36 & 14 & 32 & 11 & 24 & 16 & 40 \\
\hline S8 & ND & ND & ND & ND & ND & ND & ND & ND & ND & ND \\
\hline S9 & 12 & 36 & 9 & 22 & 16 & 45 & 11 & 36 & 8 & 20 \\
\hline
\end{tabular}

$N D=$ Not detected

Comparing the results of the lovastatin produced by the 7 producer $A$. terreus strains indicated that $A$. terreus $\mathrm{S} 3$ was the most efficient strain; consequently it was selected to carry out further investigations.

\section{Effect of gamma radiation}

In a previous study a rapid screening method of A. terreus mutants for overproduction of lovastatin was reported (Vilches Ferron et al., 2005)). The authors investigated that lovastatin caused growth inhibition of C. albicans in submerged cultures and on solid medium, and when lovastatin was placed on the agar surface using a paper disk, inhibition zones were obtained on plates of $C$. albicans.

In the present study, out of 26 survival colonies of $A$. terreus S3, irradiated at dose $4 \mathrm{kGy}$, only 9 gave lovastatin titres higher than that of the parent culture 
(fig. 1). The highest titre, inhibition zone diameter $(18 \mathrm{~mm})$, obtained with the active irradiated A. terreus $\mathrm{S} 3 \gamma 8$, was three times the lovastatin production level of the original culture (6 mm, fig. 1$)$.

From the present data, it is clear that the active irradiated A. terreus S3 $\gamma 8$ isolate produced an overproduction of lovastatin and used for further studies. A detailed study of lovastatin production by $A$. terreus $\mathrm{S} 3 \gamma 8$ in $\mathrm{SmF}$ under various conditions were carried out to obtain a clear picture of the process conditions conducive to the production of higher amounts of lovastatin by this active irradiated isolate.

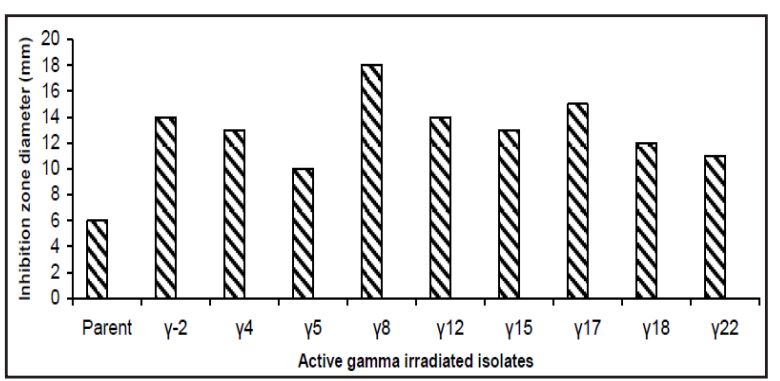

Fig. (1): Inhibition zone diameter on plates of C. albicans vs. lovastatin produced by some active gamma irradiated $A$. terreus $\mathrm{S} 3$ isolates.

\section{Influence of incubation period}

The present results showed that maximum lovastatin secretion by gamma irradiated active isolate

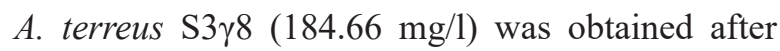
$8 \mathrm{~d}$ of incubation and then decline (table. 2). Lai, et al. (2007) found that after the stationary phase of growth, the maximum lovastatin production by A. terreus ATCC 20542 was $873 \mathrm{mg} / 1$ on day 10 . Also, 10 days were recorded as the best fermentation time for the maximum lovastatin production by A.terreus ((Lai et al., 2003 and Gupta et al., 2009). 0n the other hand, the M. paxii AM12M fermentation profile showed that, at 16 days there was already an appreciable yield of lovastatin $(117 \mathrm{mg} / \mathrm{l})$, after which it slowly increased to reach $127 \mathrm{mg} / \mathrm{l}$ at 21 days (Manzoni et al., 1999). Decline of lovastatin production after $10 \mathrm{~d}$ was related to the insufficient availability of both carbon and nitrogen sources and/ or increasing the broth viscosity at the latter stages of fermentation (12-14d) due to the built up of biomass concentration (Kumar et al., 2000 and DominguezEspinosa and Webb, 2003).

Table (2) : Time course of lovastatin production by A. terreus $S 3 \gamma 8$ grown on production medium PMII.

\begin{tabular}{|c|c|c|c|c|c|c|}
\hline $\begin{array}{c}\text { Time/ } \\
\text { day }\end{array}$ & $\begin{array}{c}\text { Consumed } \\
\text { sugar } \\
(\mathbf{g} / \mathbf{I})\end{array}$ & $\begin{array}{c}\text { Biomass } \\
(\mathbf{g} / \mathbf{I})\end{array}$ & $\begin{array}{c}\text { Lovastatin } \\
(\mathbf{m g} / \mathbf{I})\end{array}$ & $\begin{array}{c}\text { Biomass yield } \\
\text { coefficient }\end{array}$ & $\begin{array}{c}\text { Lovastatin } \\
\text { yield } \\
\text { coefficient }\end{array}$ & $\begin{array}{c}\text { Lovastatin } \\
\text { Productivity } \\
(\mathbf{m g} / \mathbf{I} / \mathbf{h})\end{array}$ \\
\hline 2 & 6.52 & 0.75 & $7.2 \pm 0.67$ & 0.12 & 1.10 & 0.15 \\
\hline 4 & 13.41 & 2.12 & $33.93 \pm 1.67$ & 0.16 & 2.53 & 0.35 \\
\hline 6 & 17.23 & 4.30 & $91.33 \pm 2.03$ & 0.25 & 5.30 & 0.63 \\
\hline 8 & 21.82 & 5.92 & $184.66 \pm 4.33 * *$ & 0.27 & 8.50 & 0.97 \\
\hline 10 & 25.24 & 6.31 & $136 \pm 2.65$ & 0.24 & 5.41 & 0.61 \\
\hline 12 & 28.10 & 6.14 & $104.33 \pm 3.28$ & 0.22 & 3.71 & 0.40 \\
\hline
\end{tabular}

* Mean $\pm S E$

** Significant from all values $(P<0.01)$

\section{Effect of initial pH}

Hydrogen ion concentration $(\mathrm{pH})$ of the medium is considered one of the most important factors, which not only affected the growth of microorganisms but also has great influence on their physiological activity. In the present work, it was found that the maximum lovastatin $(205.66 \mathrm{mg} / \mathrm{l})$ production by $A$. terreus $\mathrm{S} 3 \gamma 8$ was obtained at $\mathrm{pH} 6$ (table 3). In agreement, Sayyad, et al. (2007); Kumar, et al. (2000); Chang, et al. (2002); Jia, et al. (2009) and Li, et al. (2011) reported that the optimum $\mathrm{pH}$ for lovastatin production by various Monascus and As- 
pergillus spp. was obtained at $\mathrm{pH}$ 5-6.5. On the other hand, Lai et al. (2005) found that $\mathrm{pH}$ in the process of lovastatin production by $A$. terreus in $\mathrm{SmF}$ does not play a significant role, as it usually remains around neutral, and does not require to be adjusted during the process.

Table (3) : Effect of $p H$ values on lovastatin production by A. terreus $S 3 \gamma 8$ grown on PMII.

\begin{tabular}{|c|c|c|c|c|c|c|}
\hline $\begin{array}{c}\text { Initial } \\
\mathbf{p H}\end{array}$ & $\begin{array}{c}\text { Consumed } \\
\mathbf{s u g a r} \\
(\mathbf{g} / \mathbf{I})\end{array}$ & $\begin{array}{c}\text { Biomass } \\
(\mathbf{g} / \mathbf{I})\end{array}$ & $\begin{array}{c}\text { Lovastatin } \\
(\mathbf{m g} / \mathbf{I}) *\end{array}$ & $\begin{array}{c}\text { Biomass yield } \\
\text { coefficient }\end{array}$ & $\begin{array}{c}\text { Lovastatin } \\
\text { yield } \\
\text { coefficient }\end{array}$ & $\begin{array}{c}\text { Lovastatin } \\
\text { Productivity } \\
(\mathbf{m g} / \mathbf{I} / \mathbf{h})\end{array}$ \\
\hline 4 & 26.34 & 5.62 & $146.66 \pm 3.49$ & 0.21 & 5.61 & 0.80 \\
\hline 5 & 28.52 & 6.33 & $183 \pm 3.79$ & 0.22 & 6.42 & 0.95 \\
\hline 6 & 28.13 & 5.90 & $205.66 \pm 4.63 * *$ & 0.21 & 7.32 & 1.10 \\
\hline 7 & 22.42 & 4.25 & $71.33 \pm 3.53$ & 0.19 & 3.20 & 0.40 \\
\hline 8 & 13.25 & 2.84 & $26 \pm 2.31$ & 0.21 & 1.96 & 0.14 \\
\hline
\end{tabular}

* Mean $\pm S E$

** Significant from all values $(P<0.01)$

\section{Effect of incubation temperature}

Temperature is one of the most important parameters regulating the activity of microorganisms in natural environments. Generally, there is an optimal temperature for the activity of enzymes produced by different microorganisms which responsible for the biosynthesis or degradation of compounds. This optimal temperature may be similar or different from the optimal temperature of the microbial growth. In this study, it was observed that incubation temperature $30^{\circ} \mathrm{C}$ was the optimum temperature for maximum lovastatin $(198.33 \mathrm{mg} / \mathrm{l})$ production by $A$. ter- reus S3r8 (table 4). Similarly, Kumar, et al. (2000); Jia, et al. (2009) and Azeem, et al. (2018) found that the optimum temperature for lovastatin production by $A$. terreus was $28^{\circ} \mathrm{C}$. Also, Sayyad, et al. (2007) and Suwannarat, et al. (2019) reported that the optimum temperature for lovastatin production by $M$. purpureus MTCC 369 and A. terreus was 30 and $25^{\circ} \mathrm{C}$, respectively. Temperature influences the response of microorganisms directly by its effect on growth rate, enzyme activity, cell composition and nutritional requirements.

Table (4) : Effect of incubation temperature on lovastatin production by A. terreus S3y8 grown on PMII.

\begin{tabular}{|c|c|c|c|c|c|c|}
\hline $\begin{array}{c}\text { Temp } \\
\left({ }^{\circ} \mathbf{C}\right)\end{array}$ & $\begin{array}{c}\text { Consumed } \\
\text { sugar } \\
(\mathbf{g} / \mathbf{I})\end{array}$ & $\begin{array}{c}\text { Biomas } \\
(\mathbf{g} / \mathbf{I})\end{array}$ & $\begin{array}{c}\text { Lovastatin } \\
(\mathbf{m g} / \mathbf{I})\end{array}$ & $\begin{array}{c}\text { Biomass yield } \\
\text { coefficient }\end{array}$ & $\begin{array}{c}\text { Lovastatin } \\
\text { yield } \\
\text { coefficient }\end{array}$ & $\begin{array}{c}\text { Lovastatin } \\
\text { Productivity } \\
(\mathbf{m g} / \mathbf{I} / \mathbf{h})\end{array}$ \\
\hline 20 & 24.82 & 4.22 & $115.33 \pm 3.76$ & 0.17 & 4.70 & 0.60 \\
\hline 25 & 27.31 & 6.14 & $171 \pm 3.68$ & 0.22 & 6.30 & 0.90 \\
\hline 30 & 28.24 & 5.83 & $198.33 \pm 5.04^{* *}$ & 0.21 & 7.02 & 1.03 \\
\hline 35 & 21.73 & 3.62 & $89.33 \pm 3.53$ & 0.17 & 4.11 & 0.51 \\
\hline
\end{tabular}

* Mean \pm SE

** Significant from all values $(P<0.01)$ 


\section{Effect of carbon sources}

Carbon sources serve three different functions within the microbial cell forming lovastatin; carbon source for biomass synthesis, an energy source for biosynthesis and cell maintenance and carbon source for lovastatin production. It was found that lovastatin production by the $A$. terreus $\mathrm{S} 3 \gamma 8$ strain, under investigation, are highly influenced by different type of carbon sources. Starch was the best carbon source for lovastatin $(263.33 \mathrm{mg} / \mathrm{l})$ production in this study (table 5). The volumetric production of $A$. terreus lovastatin in submerged media is higher with lactose (Casas Lopez et al., 2003 and Lai et al., 2007). Li, et al. (2011) observed that glycerol and soluble starch was the best carbon sources for production of lovastatin by mutant of $A$. terreus CA99.

Lovastatin synthesis in this study was closely related to the amount of starch. The starch concentration $40 \mathrm{~g} / \mathrm{l}$ was the optimum concentration to maximum lovastatin $(328.33 \mathrm{mg} / \mathrm{l})$ production and increasing the starch concentration above $40 \mathrm{~g} / \mathrm{l}$ caused inhibition in the lovastatin production, in this study (table. 6). This result was also confirmed by $\mathbf{L i}$, et al. (2011) who reported that glycerol and soluble starch $(30 \mathrm{~g} / \mathrm{l})$ in the chemically defined medium gave the highest yield of lovastatin produced by mutant of $A$. terreus CA99. The increased amount of starch in the medium caused an increase in the medium viscosity, which led to poor medium aeration of the culture and consequently lovastatin production was minimal.

Table (5) : Effect of different carbon sources on lovastatin production by A. terreus S3y8 grown on PMII.

\begin{tabular}{|c|c|c|c|c|c|c|}
\hline $\begin{array}{c}\text { Sugar } \\
\text { sources } \\
(\mathbf{3 0 g} / \mathbf{I})\end{array}$ & $\begin{array}{c}\text { Consumed } \\
\text { sugar } \\
(\mathbf{g} / \mathbf{I})\end{array}$ & $\begin{array}{c}\text { Biomass } \\
(\mathbf{g} / \mathbf{I})\end{array}$ & $\begin{array}{c}\text { Lovastatin } \\
(\mathbf{m g} / \mathbf{I})\end{array}$ & $\begin{array}{c}\text { Biomass } \\
\text { yield } \\
\text { coefficient }\end{array}$ & $\begin{array}{c}\text { Lovastatin } \\
\text { yield } \\
\text { coefficient }\end{array}$ & $\begin{array}{c}\text { Lovastatin } \\
\text { Productivity } \\
(\mathbf{m g} / \mathbf{I} / \mathbf{h})\end{array}$ \\
\hline $\begin{array}{c}\text { Dextrose } \\
\text { «control» }\end{array}$ & 28.24 & 5.92 & $193.66 \pm 6.12$ & 0.21 & 6.91 & 1.01 \\
\hline Sucrose & 26.52 & 6.13 & $140.66 \pm 3.49$ & 0.23 & 5.30 & 0.73 \\
\hline Fructose & 17.30 & 4.22 & $84.33 \pm 2.33$ & 0.24 & 4.87 & 0.44 \\
\hline Starch & 28.64 & 5.67 & $263.33 \pm 5.24 * *$ & 0.20 & 9.20 & 1.40 \\
\hline Maltose & 18.50 & 4.41 & $96.66 \pm 3.49$ & 0.24 & 5.23 & 0.50 \\
\hline Lactose & 25.42 & 6.30 & $231 \pm 3.79$ & 0.25 & 9.11 & 1.20 \\
\hline Manitol & 13.15 & 3.72 & $44.33 \pm 1.76$ & 0.28 & 3.37 & 0.23 \\
\hline Xylose & 12.6 & 3.31 & $33 \pm 2.10$ & 0.26 & 2.62 & 0.20 \\
\hline
\end{tabular}

* Mean \pm SE

** Significant from all values $(P<0.01)$

Table (6) : Effect of different starch concentrations on lovastatin production by A. terreus $S 3 \gamma 8$ grown on PMII.

\begin{tabular}{|c|c|c|c|c|c|c|}
\hline $\begin{array}{c}\text { Starch } \\
\text { Conc. } \\
(\mathbf{g} / \mathbf{I})\end{array}$ & $\begin{array}{c}\text { Consumed } \\
\text { sugar } \\
(\mathbf{g} / \mathbf{I})\end{array}$ & $\begin{array}{c}\text { Biomass } \\
(\mathbf{g} / \mathbf{I})\end{array}$ & $\begin{array}{c}\text { Lovastatin } \\
(\mathbf{m g} / \mathbf{I})\end{array}$ & $\begin{array}{c}\text { Biomass } \\
\text { yield } \\
\text { coefficient }\end{array}$ & $\begin{array}{c}\text { Lovastatin } \\
\text { yield } \\
\text { coefficient }\end{array}$ & $\begin{array}{c}\text { Lovastatin } \\
\text { Productivity } \\
(\mathbf{m g} / \mathbf{I} / \mathbf{h})\end{array}$ \\
\hline 10 & 9.62 & 2.84 & $25.33 \pm 2.03$ & 0.31 & 2.63 & 0.13 \\
\hline 20 & 19.14 & 4.15 & $83 \pm 3.22$ & 0.22 & 4.34 & 0.43 \\
\hline 30 & 28.50 & 5.61 & $261.66 \pm 5.55$ & 0.21 & 9.20 & 1.40 \\
\hline 40 & 36.22 & 6.80 & $328.33 \pm 4.91^{* *}$ & 0.21 & 9.10 & 1.71 \\
\hline 50 & 41.83 & 7.52 & $284.66 \pm 4.33$ & 0.20 & 6.81 & 1.50 \\
\hline 60 & 52.61 & 8.40 & $211.66 \pm 3.76$ & 0.21 & 4.02 & 1.10 \\
\hline
\end{tabular}

* Mean \pm SE

** Significant from all values $(P<0.01)$ 


\section{Effect of nitrogen sources}

Nitrogen sources appear to be one of the most effective factors for the microbial lovastatin production (Casas Lopez et al., 2003). Studies on several organic and inorganic nitrogen sources showed that yeast extract was the best nitrogen source for lovastatin $(415.33 \mathrm{mg} / \mathrm{l})$ production by $A$. terreus $\mathrm{S} 3 \gamma 8$, strain under investigation (table 7). Organic nitrogen sources (peptone and yeast extract) and corn meal were recorded as the best nitrogen sources for production of microbial lovastatin (Manzoni et al., 1998; Casas Lopez et al., 2003; Li et al., 2011 and Azeem et al., 2018).

The development of a nutrient strategy is crucial to the success of the fermentation process. Lovastatin production need to be balanced to avoid incomplete secretion of it. This may be achieved by balancing the carbon/nitrogen ratio. In the present investigation, the maximum lovastatin production by

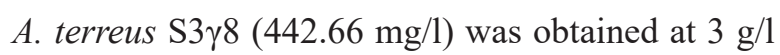
yeast extract concentration (table 8 ). Under the nitrogen sufficient condition, Manzoni, et al. (1998);
Kumar, et al. (2000); Chang, et al. (2002); Sayyad, et al. (2007) and Li, et al. (2011) found that the $A s$ pergillus and Monascus spp. produced the highest lovastatin concentrations.

\section{Effect of inoculum type}

Despite the importance of inoculum development little work has been published that addresses the prloblem of inoculum optimization (DeTilly et al., 1983). For lovastatin production by fungi in $\mathrm{SmF}$, three main inoculation types been used: spore suspension, mycelial mat and seed culture (Novak et al., 1997; Casas Lopez et al., 2003 and Lai et al., 2003). The present results showed that seed culture inoculum $48 \mathrm{~h}$ age of $A$. terreus $\mathrm{S} 3 \gamma 8$ at density $10 \%$ $\mathrm{v} / \mathrm{v}$ was the best inoculum preparation for the lovastatin (545.33 mg/l) production (table 9). Sayyad, et al. (2007) used seed culture inoculum $48 \mathrm{~h}$ age at density $10 \%$ (v/v) for M. purpureus MTCC 369 lovastatin production. On the other hand $5 \%(\mathrm{v} / \mathrm{v})$ of seed culture inoculum (4 old days) was used as inoculum for M. ruber ATCC 18199 lovastatin production (Chang et al., 2002).

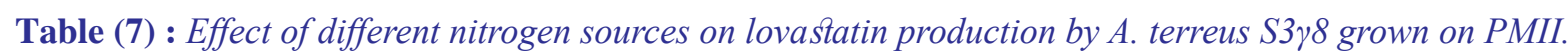

\begin{tabular}{|c|c|c|c|c|c|c|}
\hline $\begin{array}{c}\text { Nitrogen } \\
\text { sources (3.86 } \\
\mathbf{g} / \mathbf{I})\end{array}$ & $\begin{array}{c}\text { Consumed } \\
\text { sugar } \\
(\mathbf{g} / \mathbf{I})\end{array}$ & $\begin{array}{c}\text { Biomass } \\
(\mathbf{g} / \mathbf{I})\end{array}$ & $\begin{array}{c}\text { Lovastatin } \\
(\mathbf{m g} / \mathbf{I})\end{array}$ & $\begin{array}{c}\text { Biomass } \\
\text { yield } \\
\text { coefficient }\end{array}$ & $\begin{array}{c}\text { Lovastatin } \\
\text { yield } \\
\text { coefficient }\end{array}$ & $\begin{array}{c}\text { Lovastatin } \\
\text { Productivity } \\
\text { (mg/I/h) }\end{array}$ \\
\hline $\begin{array}{c}\mathrm{NH}_{4} \mathrm{Cl} \text { "control" } \\
\text { "coln }\end{array}$ & 36.52 & 6.83 & $334 \pm 4.73$ & 0.19 & 9.15 & 1.74 \\
\hline $\mathrm{NaNO}_{3}$ & 33.62 & 6.13 & $241.33 \pm 5.24$ & 0.18 & 7.20 & 1.30 \\
\hline $\mathrm{KNO}_{3}$ & 28.83 & 5.42 & $193.33 \pm 5.24$ & 0.21 & 6.71 & 1.01 \\
\hline$\left(\mathrm{NH}_{4}\right)_{2} \mathrm{SO}_{4}$ & 35.40 & 7.22 & $353.33 \pm 5.81$ & 0.20 & 9.98 & 1.84 \\
\hline $\begin{array}{c}\text { Mycological } \\
\text { peptone }\end{array}$ & 37.14 & 7.60 & $382.33 \pm 7.31$ & 0.20 & 10.30 & 2.10 \\
\hline Yeast extract & 36.81 & 6.62 & $415.33 \pm 6.64 * *$ & 0.21 & 11.30 & 2.20 \\
\hline Tryptone & 34.20 & 7.41 & $226.33 \pm 4.91$ & 0.22 & 6.62 & 1.21 \\
\hline Beef extract & 35.22 & 7.13 & $261.66 \pm 6.12$ & 0.20 & 7.43 & 1.40 \\
\hline
\end{tabular}

* Mean \pm SE

** Significant from all values $(P<0.01)$ 
Table (8) : Effect of yeast extract concentration on lovastatin production by A. terreus S3y8 grown on PMII.

\begin{tabular}{|c|c|c|c|c|c|c|}
\hline $\begin{array}{c}\text { Yeast } \\
\text { extract } \\
\text { conc. }(\mathbf{g} / \mathbf{I})\end{array}$ & $\begin{array}{c}\text { Consumed } \\
\text { sugar } \\
(\mathbf{g} / \mathbf{I})\end{array}$ & $\begin{array}{c}\text { Biomass } \\
(\mathbf{g} / \mathbf{I})\end{array}$ & $\begin{array}{c}\text { Lovastatin } \\
(\mathbf{m g} / \mathbf{I})\end{array}$ & $\begin{array}{c}\text { Biomass } \\
\text { yield } \\
\text { coefficient }\end{array}$ & $\begin{array}{c}\text { Lovastatin } \\
\text { yield } \\
\text { coefficient }\end{array}$ & $\begin{array}{c}\text { Lovastatin } \\
\text { Productivity } \\
(\mathbf{m g} / \mathbf{I} / \mathbf{h})\end{array}$ \\
\hline 1 & 31.50 & 5.21 & $274 \pm 4.36$ & 0.17 & 8.71 & 1.43 \\
\hline 2 & 35.82 & 6.40 & $382.33 \pm 7.31$ & 0.18 & 10.70 & 2.11 \\
\hline 3 & 36.84 & 6.62 & $442.66 \pm 6.94 * *$ & 0.21 & 12.01 & 2.30 \\
\hline 4 & 36.60 & 6.51 & $394 \pm 6.43$ & 0.21 & 10.81 & 2.10 \\
\hline 5 & 31.42 & 5.52 & $234 \pm 4.36$ & 0.18 & 7.50 & 1.22 \\
\hline 6 & 25.30 & 4.11 & $179 \pm 3.80$ & 0.16 & 7.11 & 0.93 \\
\hline
\end{tabular}

*Mean $\pm S E$

** Significant from all values $(P<0.01)$

Table (9) : Effect of type of A. terreus $S 3 \gamma 8$ inocula on lovastatin production from optimized PMII (OPMII).

\begin{tabular}{|c|c|c|c|c|c|c|}
\hline $\begin{array}{c}\text { Inoculum } \\
\text { type }\end{array}$ & $\begin{array}{c}\text { Consumed } \\
\text { sugar, } \\
(\mathbf{g} / \mathbf{I})\end{array}$ & $\begin{array}{c}\text { Biomass } \\
(\mathrm{g} / \mathrm{I})\end{array}$ & $\begin{array}{c}\text { Lovastatin } \\
(\mathbf{m g} / \mathbf{I})\end{array}$ & $\begin{array}{c}\text { Biomass } \\
\text { yield } \\
\text { coefficient }\end{array}$ & $\begin{array}{c}\text { Lovastatin } \\
\text { yield } \\
\text { coefficient }\end{array}$ & $\begin{array}{c}\text { Lovastatin } \\
\text { Productivity } \\
(\mathbf{m g} / \mathbf{I} / \mathbf{h})\end{array}$ \\
\hline $\begin{array}{c}\text { Spore } \\
\text { suspension, } 1 \% \\
(\text { Control })\end{array}$ & 36.80 & 6.61 & $482.66 \pm 7.62$ & 0.18 & 13.12 & 2.51 \\
\hline $\begin{array}{c}\text { Seed culture } \\
\text { (Age,48 } \\
\text { h;10\% })\end{array}$ & 37.52 & 6.80 & $545.33 \pm 7.51^{* * *}$ & 0.18 & 14.53 & 2.84 \\
\hline $\begin{array}{c}\text { Mycelium } \\
\text { Disc } 1 \mathrm{~cm}, 7 \\
\text { days old }\end{array}$ & 35.41 & 6.22 & $346.33 \pm 6.64$ & 0.19 & 9.80 & 1.80 \\
\hline
\end{tabular}

*Mean $\pm S E$

** Significant from all values $(P<0.01)$

\section{Effect of agitation speed}

It has been reported that agitation (oxygen transfer) is one of the key parameters for the process optimization and scale -up of lovastatin production by fungi (Su et al., 2003 and Sayyad et al., 2007). It is apparent from the result that the productivity of A. terreus $\mathrm{S} 3 \gamma 8$ lovastatin varies considerably during static and shaking conditions (table 10). More lovastatin was found to be produced in shaking conditions as compared to static one, and $150 \mathrm{rpm}$ was the best agitation speed for lovastatin $(547.33 \mathrm{mg} / \mathrm{l})$ production, in this study, but a further increase (200 $\mathrm{rpm}$ ) was not associated with a better production. Lai et al. (2003) and Azeem et al. (2018) mentioned that the production of A.terreus lovastatin have mainly based on agitation speed on $200 \mathrm{rpm}$. In contrast agitation rate $(60 \mathrm{rpm})$ were used for maximize several Monascus and Aspergillus spp. statins production (Manzoni et at., 1999). Morphological changes and destruction of the pellets were associated with the high agitation rate (in this study) resulting in high shear conditions. These morphological changes are certainly related to physiological changes resulting in a lower production of secondary metabolites (Hajjaj et al., 1999). 
Table (10): Effect of agitation on lovastatin production by A. terreus $S 3 \gamma 8$ on OPMII.

\begin{tabular}{|c|c|c|c|c|c|c|}
\hline $\begin{array}{c}\text { Agitation } \\
\text { speed } \\
(\mathbf{r p m})\end{array}$ & $\begin{array}{c}\text { Consumed } \\
\text { sugar } \\
(\mathbf{g} / \mathbf{I})\end{array}$ & $\begin{array}{c}\text { Biomass } \\
(\mathbf{g} / \mathbf{I})\end{array}$ & $\begin{array}{c}\text { Lovastatin } \\
(\mathbf{m g} / \mathbf{I})\end{array}$ & $\begin{array}{c}\text { Biomass } \\
\text { yield } \\
\text { coefficient }\end{array}$ & $\begin{array}{c}\text { Lovastatin } \\
\text { yield } \\
\text { coefficient }\end{array}$ & $\begin{array}{c}\text { Lovastatin } \\
\text { Productivity } \\
(\mathbf{m g} / \mathbf{I} / \mathbf{h})\end{array}$ \\
\hline 0 (static) & 25.20 & 7.12 & $113.66 \pm 4.10$ & 0.28 & 4.51 & 0.60 \\
\hline 50 & 30.41 & 5.80 & $210 \pm 4.62$ & 0.20 & 7.01 & 1.10 \\
\hline 100 & 32.53 & 6.22 & $293.33 \pm 5.24$ & 0.19 & 9.02 & 1.53 \\
\hline 150 & 37.40 & 6.81 & $547.33 \pm 5.81^{* *}$ & 0.18 & 14.63 & 2.86 \\
\hline 200 & 37.12 & 6.52 & $327 \pm 5.51$ & 0.17 & 8.81 & 1.70 \\
\hline 250 & 35.20 & 5.30 & $240 \pm 4.62$ & 0.15 & 7.02 & 1.25 \\
\hline
\end{tabular}

*Mean $\pm S E$

** Significant from all values $(P<0.01)$

In conclusion, the social progress and the riseup of human living standards, more and more attention has been paid on the health cares. Lovastatin $\left(\mathrm{C}_{24} \mathrm{H}_{36} \mathrm{O}_{5}\right)$ is the first compound of its kind to become available for treatment of hypercholesterolemia. This fungal secondary metabolite is produced by Aspergillus terreus, Monascus species and Penicillium species, via the polyketide synthase (PKSs). The present work has been devoted to studying the effect of different parameters on lovastatin production by the local isolated strain of $A$. terreus. The production of lovastatin by gamma irradiated isolate (A. terreus $\mathrm{S} 3 \gamma 8$ ) in $\mathrm{SmF}$ is not a novel idea, but, limited information is available on culture parameters influencing lovastatin production by this method. Therefore, this study mainly investigated how much the physical and nutritional fermentation parameters affect the yield of lovastatin production by $A$. terreus S3 $\gamma 8$. However, scales up studies are still necessary to further optimize the proposed process and to evaluate its techno-economical feasibility.

\section{REFERENCES}

- $\quad$ Azeem, M.; Saleem, Y.; Hussain, Z.; Zahoor, S. and Javed, M.M. (2018): Optimization of culture conditions for the production of lovastatin by $A s$ pergillus terreus in submerged fermentation. Pharm. Chem. J., 52: 284.
- Barrios-González, J. and Miran da, R.U. (2010): Biotechnological production and applications of statins. Appl. Microbiol. Biotechnol., 85: 869.

- Bizukojc, M. and Ledakowicz, S. (2015): Bioprocess engineering aspects of the cultivation of a lovastatin producer Aspergillus terreus. Adv. Biochem. Engin. Biotechnol., 149, DOI: 10.1007/10_2014_302

- Casas-López, J.L.; Sánchez-Pérez, J.A.; Fernández-Sevilla, J. M.; Acién-Fernández, F. G.; Molina-Grima, E. and Chisti, Y. (2003): Production of lovastatin by Aspergillus terreus: effects of the C: N ratio and the principal nutrients on growth and metabolite production. Enzyme Microb. Technol., 33: 270.

- Chang, Y.-N.; Huang, J.-C.; Lee, C.-C.; Shih, I.-L. and Tzeng, Y.-M. (2002): Use of response surface methodology to optimize culture medium for production of lovastatin by Monascus ruber. Enzyme Microb. Technol., 30: 889.

- DeTilly, G.; Mou, D. and Gooney, C. (1983): Optimization and Economics of Antibacterial Production. In: Smith, J.E.; Berry, D.R. and Kristiansen, B.K. (eds.). The Filamentous Fungi. Vol.4. Fungal Technology. Edward Arnold Publ.

- Dominguez-Espinosa, R. and Webb, C. (2003): Submerged fermentation in wheat substrates for Production of Monascus pigments. World J. Microbiol. Biotechnol., 19: 329. 
- Furberg, C.D. (1999): Natural statins and stroke risk. Circulation, 99: 185.

- Gu, S.B.; Li, S.C.; Feng, H.Y.; Wu, Y. and Yu, Z.L. (2008): A novel approach too microbial breeding-low energy ion implantation. Appl. Microbiol. Biotechnol., 78: 201.

- Gupta, K.; Mishra, P.K. and Srivastava, P. (2009): Enhanced continuous production of lovastatin using pellets and siran supported growth of Aspergillus terreus in an airlift reactor. Biotechnol. Bioprocess Eng., 14: 207 .

- Hajjaj, H.; Blanc, P.; Groussac, E.; Goma, G.; Uribelarrea, J. and Loubiere, P. (1999): Improvement of red pigment/ citrinin production ratio as a function of environmental conditions by Monascus rubber. Biotechnol. Bioeng., 64: 497.

- Hajko, P.; Vesel, T.; Radez, I. and Pokorny, M. (1998): Process for the isolation of lovastatin. United States Patent, 5,712,130, Jan. 27.

- Iewkittayakorn, J.; Kuechoo1, K.; Sukpondma, Y.; Rukachaisirikul, V.; Phongpaichit, S. and Chotigeat, W. (2020): Lovastatin production by $A s$ pergillus sclerotiorum using agricultural waste. Food Technol. Biotechnol., 58: 230.

- Jia, Z.; Zhang, X.; Zhao, Y. and Cao, X. (2009): Effects of divalent metal cations on lovastatin biosynthesis from Aspergillus terreus in chemically defined medium. World J. Microbiol. Biotechnol., 25: 1235.

- Kumar, M.S.; Jana, S.K.; Senthil, V.; Shashanka, V.; Kumar, S.V. and Sadhukhan, A.K. (2000): Repeated fed-batch process for improving lovastatin production. Process Biochem., 36: 363.

- Lai, L.-S.; Hung, C.-S. and Lo, C.-C. (2007): Effects of lactose and glucose on production of itaconic acid and lovastatin by Aspergillus terreus ATCC 20542. J. Biosci. Bioeng., 104: 9.

- Lai, L.-S.; Pan, C.-C. and Tzeng, B.-K. (2003): The influence of medium design on lovastatin production and pellet formation with a high-producing mutant of
Aspergillus terreus in submerged cultures. Process Biochem., 38: 1317.

- Lai, L.-S.; Tsai, T.-H.; Wang, T.C., Cheng, T.-Y. (2005): The influence of culturing environments on lovastatin production by Aspergillus terreus in submerged cultures. Enzyme Microb. Technol., 36: 737.

- Li, S.-W.; Li, M.; Song, H.-P.; Feng, J.-L. and Tai, X.-S. (2011): Induction of a high-yield lovastatin mutant of Aspergillus terreus by c heavy-ion beam irradiation and the influence of culture conditions on lovastatin production under submerged fermentation. Appl. Biochem. Biotechnol., 165: 913.

- Manzoni, M. and Rollini, M. (2002): Biosynthesis and biotechnological production of statins by filamentous fungi and application of these cholesterollowering drugs. Appl. Microbiol. Biotechnol., 58: 555 .

- Manzoni, M.; Bergomi, S.; Rollini, M. and Cavazzoni, V. (1999): Production of statins by filamentous fungi. Biotechnol. Lett., 21: 253.

- Manzoni, M.; Rollini, M.; Bergomi, S. and Cavazzoni, V. (1998): Production and purification of statins from Aspergillus terreus strains. Biotechnol. Techniques, 12: 529.

- Munir, N.; Asghar, M.; Murtaza, M.A.; Akhter, N.; Rasool, G.; Shah, S.M.A.; Tahir, I.M.; Khan, F.S.; Riaz, M.; Sultana, S.; Rashid, A.; Akhlaq, M. and Akram, M. (2018): Enhanced production of Lovastati $\mathrm{n}$ by filamentous fungi through solid state fermentation. Pak. J. Pharm. Sci., 31: 1583.

- Novak, N., Gerdin, S. and Berovic, M. (1997): Increased lovastatin formation by Aspergillus terreus using repeated fed batch process. Biotech. Lett. 19: 947.

- Oxoid (2006): The Oxoid Manual of Cultural Media Ingredients and other Laboratory Services. $4^{\text {th }}$ ed. Publ. Oxoid limited, Wade Road, Basingstoke, Hampshire RG24 PW. 
- Sayyad, S.A.; Panda, B.P.; Javed, S. and Ali, M. (2007): Optimization of nutrient parameters for lovastatin production by Monascus purpureus MTCC 369 under submerged fermentation using response surface methodology. Appl. Microbiol. Biotechnol., 73:1054.

- Southgate, D. A. T. (1976): Determination of Food Carbohydrates. Appl. Sci. Publ. LTD., London, pp. 99-144.

- Su, Y.C.; Wang, J.J.; Lin, T.T. and Pan, T.M. (2003): Production of secondary metabolites, $\gamma$-amino butyric acid and monacolin $\mathrm{K}$ by Monascus. J. Ind Microbiol. Biotechnol., 30: 41.

- Subhan, M.; Faryal, R. and Macreadie, I. (2020): Utilization of an industry byproduct, Corymbia maculata leaves, by Aspergillus terreus to produce lovastatin. Bioengineering, 7(3): 101
- Suwannarat, S.; Iewkittayakorn, J.; Sukpondma, Y.; Rukachaisirikul, V.; Phongpaichit, S. and Chotigeat, W. (2019): Optimization of the production of lovastatin from Aspergillus sclerotiorum PSURSPG178 under static liquid culture using response surface methodology. Sains Malaysiana., 48: 93.

- Vilches Ferron, M.A.; Casas Lopez, J.L.; Sanchez Perez1, J.A.; Fernandez Sevilla, J.M. and Chisti, Y. (2005): Rapid screening of Aspergillus terreus mutants for overproduction of lovastatin. World J. Microbiol. Biotechnol., 21: 123.

- World Health organization (2017): Cardiovascular diseases (CVDs). http://www.who.int/news-room/ factsheets/ detail/cardiovascular-diseases-(cvds). 